to which their knowledge is made to serve inhuman ends. The possibilities before humanity have been fairly set out by a recent historian, H. A. L. Fisher: "The developing miracle of science is at our disposal to use or to abuse, to make or to mar. With science we may lay civilization in ruins, or enter into a period of plenty and well-being, the like of which has never been experienced by mankind". To the clearing of this conflicting situation, the scientific worker has not always made the constructive contribution which he might have done : he has been content to adopt an objective and detached attitude, suggesting sometimes com- plete indifference to the wider human issues at stake, assenting too readily to the misuse of his knowledge and skill. Impelled by patriotic motives, most men of science have put themselves freely at the disposal of the State in time of need, but many are hesitating to admit that patriotism must always override considerations of humanity. Whatever be our individual attitude in this matter, it is time for chemists and scientists in general to throw their weight into the scale against the tendencies which are dragging science and civilization down and debasing our heritage of intellectual and spiritual values.

\title{
Obituary
}

\section{Prof. A. P. Karpinsky}

Prof. Alexander Petrovich Karpinsky, the greatest of Soviet geologists, president of the Academy of Sciences of the U.S.S.R., of which he had been a member for fifty years, died on July 15 in his ninetieth year. He was a foreign member of many learned bodies; the Geological Society of London elected him a foreign member in 1901 and awarded him the Wollaston Medal in 1916.

An entire epoch in the history of Russian geology, following that of Murchison (the forties of the past century), is connected with Karpinsky's name. Karpinsky compiled a new, much more detailed geological map of the European part of the U.S.S.R. and the Urals. This map was the ground-work of the Russian geological service, of which he was one of the creators, and which was then known as the Geological Committee. Being during many years practically the head and leader of that institution, the staff of which was mainly composed of his pupils, Karpinsky was the creator of the new stratigraphy of Russia. This, however, does not exhaust the significance of Karpinsky's work in the history of geology. He was the last of those geologists who embraced the whole of geological science, working with equal skill in every branch of it.

Karpinsky's personal field-work in stratigraphy concerned all the systems and various regions of the European part of the U.S.S.R., but mainly the Urals ; he was the first to solve the enigma of the eastern slope of the latter. His contributions which demonstrated the tectonic structure of the Russian platform were only completed, never reconstructed by later explorers, and were of immense value. He first established the regularity of movements of the earth's crust. Only much later did his ideas receive wider development in the theory of geosynclines.

Karpinsky's palæontological studies are of no less importance. Of his works on invertebrates the most remarkable are those concerning the palæozoic ammonoids. He was one of the first to apply the ontogenetic method, and not to single forms, but to a whole fauna. This led to most important conclusions both zoological and geological (he proved the evolution of the Artinskian fauna in situ, whereas it was considered immigrant). A most remarkable study is that on Helicoprion, a primitive shark, to the study of which he applied the histological method with brilliant results.

Particular attention may be directed to his monograph on Trochilisks-tiny Devonian algæ. To write this monograph, Karpinsky had to become a botanist. It is curious to note that in a controversy with botanists who did not share Karpinsky's opinion of these fossils, the victory went to Karpinsky. In petrology, besides special studies by which began his scientific activity, it is worth mentioning that he was the first in Russia to introduce the microscope in the study of petrographic slides.

From the very beginning of his scientific activity, Karpinsky was interested in deposits of useful minerals. $\mathrm{He}$ forecast the discovery of salt at Bakhmut, he advanced the view that petroleum deposits exist in the Urals; this has been brilliantly confirmed by recent prospecting for petroleum at Ishimbaievo, exactly in the Artinskian deposits established by Karpinsky, as well as by that at Krasnokamsk in the Middle Carboniferous. Karpinsky was particularly interested in the problem of the origin of platinum deposits; he studied some iron deposits and so on. He may be justly called the founder of the practical geology of the Urals.

Karpinsky continued working to his last days, and on his death bed he asked for paper to write down a new idea. In Karpinsky we lose not only the greatest Soviet scientist, but also an excellent man and citizen. Despite his high position, he never ceased to be modest, simple, accessible to everyone, especially to young students, at whose disposal he readily put his knowledge and experience. Injustice and untruth alone aroused his anger, and he frequently expressed his sympathy with the Soviet Government, which he used to call "the most just in the world".

\section{A. BorISSIAK.}

